\title{
Cargill, Goodman, and Young to Chair 1988 MRS Fall Meeting
}

G. Slade Cargill III, D. Wayne Goodman, and J. Francis Young have been appointed Meeting Chairs for the 1988 MRS Fall Meeting, scheduled for the week of November 28-December 3, 1988 in Boston, Massachusetts. Twenty-three topical symposia will cover the latest materials developments, characterization methods, or processing technology. A series of short courses featuring complementary topics is also planned.

"The 1988 Fall Meeting will continue the MRS philosophy of offering a broad-based spectrum of forefront topics approached in an interdisciplinary manner," says Young. "We plan to expand on this philosophy with several new thrusts," he continued, "including symposia on the chemistry of materials for electronics, liquid crystal polymers, solid state ionics, tribology, nondestructive evaluation of mechanical properties, and synchrotron radiation in materials research."

The symposia planned for the 1988 Fall Meeting are listed below. See upcoming issues of the MRS BULLETIN for more details.

G. Slade Cargill III is senior manager, Structure of Materials Department, at IBM T.J. Watson Research Center, where he has served in various capacities since 1975 . He holds a PhD in applied physics from Harvard University and has served as an instructor in the Department of Engineering and Applied Science at Yale University. During his 1979-80 sabbatical from IBM, he developed electron-acoustic microscopy, a technique for examining the thermal and elastic properties of solids with high spatial resolution. Cargill has published more than 70 technical papers in the fields of amorphous materials, magnetism, semiconductors, $\mathrm{x}$-ray scattering, and electron microscopy. He has been chairman in several capacities for the Conference on Magnetism and Magnetic Materials, co-chair of the 1978 Topical Conference on Atomic Scale Structure of Amorphous Solids, cochair of the 1985 MRS symposium on "Phase Transitions in Condensed Systems," and a member of the advisory committee for the International Conference on Rapidly Quenched Metals. He is a member of the Materials Research Society, a Fellow of the American Physical Society and has served on numerous government and university advisory committees and study groups, including the current National Science Foundation Materials Research Advisory Committee.

D. Wayne Goodman is supervisor, Surface Science Division, Sandia National Lab-

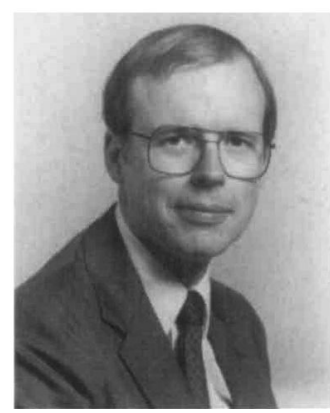

G. Slade Cargill III

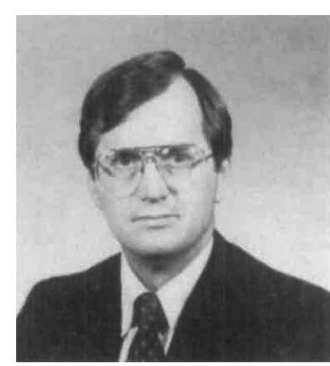

D. Wayne Goodman

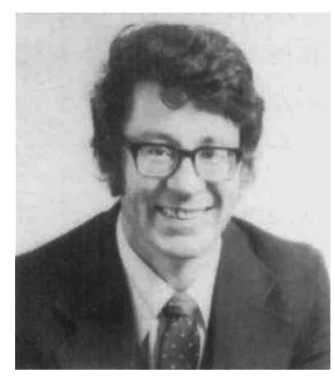

J. Francis Young

oratories. Before his appointment to the Sandia staff in 1980, he worked at the National Bureau of Standards, Washington, DC. He holds a PhD from the University of Texas, where he conducted research on photoelectron spectroscopic studies of organic molecules. His current research activities lie in two areas: chemisorption and catalytic reactions on atomically clean and chemically modified metal singlecrystal surfaces using modern surface science techniques; and the fundamental chemistry of processes which occur at the solid-gas/solid-liquid interface relating to corrosion, forming of ceramic materials, and absorption of hydrogen. Goodman has served as treasurer, vice-chairman and chairman of the American Chemical Society. He is a member of the executive committee of the American Vacuum Society, the board of editors of Applied Surface Science, the Langmuir advisory board, and the Materials Research Society.
J. Francis Young was educated in New Zealand and England, receiving a PhD in inorganic chemistry from Imperial College, University of London, in 1965 . After a brief period in New Zealand at the Chemistry Division of DSIR he moved to the Portland Cement Association in Skokie, Illinois in 1969. The following year he joined the faculty of the University of Illinois at UrbanaChampaign, where he is now professor of civil engineering and ceramic engineering and director of the Center for Cement Composite Materials. A member of the Materials Research Society, Young is also a Fellow of the American Ceramic Society and served on its board of trustees from 1984-87. His research interests are centered on the chemistry of cements and microstructure-property relationships in cementitious materials.

\section{MRS Fall Meeting Symposia}

A. Processing and Characterization of Materials Using Ion Beams

B. Laser and Particle Beam Chemical Processes on Surfaces

C. Thin Films: Stress and Mechanical Behavior

D. Advanced Methods for Characterizing the Surfaces of Materials

E. Chemistry of Materials for Electronics

F. High Temperature Superconducting Materials for Applications

G. Multicomponent Ultrafine Microstructures

H. High Temperature Ordered Intermetallic Alloys

I. Liquid Crystal Polymers

J. Rigid Rod Polymers

K. Materials Science of Calcified Tissues

L. Graphite Intercalated Compounds and Fibers

M. Solid State Ionics

N. Fractals Aspects of Materials: Disordered Systems

O. Fly Ash and Coal Conversion ByProducts

P. Pore Structure and Permeability of Cementitious Materials

Q. Characterization of Defects in Materials

R. High Resolution Microscopy of Materials

S. New Approaches to Tribology: Theory and Application

T. Atomic Scale Calculations in Materials Science

U. Nondestructive Methods for Determining Mechanical Properties of Materials

v. Synchrotron Radiation in Materials Research

$X$. Frontiers in Materials Science 